\title{
The Gendered Nature of Security in El Salvador: Challenges for Community-Oriented Policing
}

\author{
Erika J. Rojas Ospina \\ Norwegian University of Life Sciences (NMBU), Ås, Norway. E-Mail: erika.rojas@nmbu.no; Tel.: +47 67231326
}

Submitted: 27 July 2018 | In revised form: 28 September 2019 | Accepted: 28 October 2019 |

Published: 14 January 2020

\begin{abstract}
With the purge of the Military Forces and the creation of a new National Civilian Police (PNC) as mandated by the 1992 Peace Accords, El Salvador set the stage for the construction of a less state-oriented security approach. However, a failure to question issues of security and a lack of consideration of gender in the Peace negotiations and the Security Reform resulted in an overly gendered understanding of security, were the State remained as its subject and the practice privileged a militarized masculinity that has hindered the implementation of democratic policing. In this context, 25 years after the Peace Accords, the police have been unable to consolidate a democratic policing practice as oppressive policing strategies remain deeply embedded in the institution, side-by-side with heavy-handed measures that use repression to control social violence. From a feminist critical security approach, the article questions the gendered nature of security in El Salvador, and investigates the implication of the introduction of militaries into the work of the police, in terms of its symbolic influence in the gendered expectations of police men and women, and the practical impact it has on their work, e.g., the difficulty of consolidating Community-Oriented Policing. The argument is based on interviews and focus groups with police men and women, as well as with feminist organizations. The information was gathered during fieldwork in 2018 and 2019, and through extensive literature review.
\end{abstract}

Keywords: community-oriented policing; El Salvador; gender; human security; militarized-masculinity; police reform; security reform

\section{Introduction}

The greatest success of the Security Reform after the Peace Accords in El Salvador in 1992, together with the demobilization of the Farabundo Martí National Liberation Front guerrilla (FMLN, by its Spanish acronym), was the dismantling of the country's old security forces. Following this, the major triumph was the creation of a new civilian and professional police, the National Civil Police (or PNC, by its Spanish acronym).

At the start of 2017, the Salvadoran PNC celebrated the 25th anniversary of its establishment. Implicitly, this commemoration was also a celebration of democracy and the allegedly successful Security Reform. However, by the end of the same year, the police found itself facing a crisis of legitimacy caused by several cases of suicide, domestic violence, and feminicide, occurring at the heart of the institution. The country was shocked to learn from media coverage of the shooting and disappearance of the police officer Carla Ayala by another police, a member of the Police Reaction Group (or GRP, by its Spanish acronym), following a Christmas celebration party [1].This event prompted the dismantling of the GRP, but the crisis did not end there. To this case a long list of accusations of impunity, abuse of 
power, and extrajudicial killings was added [2].

These events were embarrassing for a police institution keen to celebrate a quarter of a century of existence operating under a democratic and civilian security model. Accusations of the police are not new. Indeed, it is connected to slowly increasing levels of distrust between civil society and the police, particularly to the police's abuse of force, its partisan role, and lack of accountability [3]. It also reflects the apparent inability of the police to guarantee public security under a democratic mandate in a highly violent scenario [4], and moreover, their inability to protect their members from gender-based violence within the institution.

The police are not alone in defining how security and gender relations are understood and performed in EI Salvador. As a national institution, the Salvadorian police force reflects many of the assumptions of the state, the sociocultural constructions of expected gender behaviors, and the myths that surround them. The police in El Salvador do not operate in a vacuum as they reflect the political contradictions of a post-conflict country with high levels of social and criminal violence. The contradictions involved with implementing both soft and hard security policies and practices have further added to the crisis of legitimacy of the PNC.

Considering the wider background of this case, I aim to demonstrate in this article that the crisis reflects a longer history of challenges within the Salvadoran police, and that two major persisting difficulties rest in the understanding of gender and security. I argue that the crisis demonstrates the lack of a gendered approach to the Peace Accords and the Security Reform process. It also suggests that a limited understanding of security and blindness to gender, both on the political and technical level, has enabled the gradual militarization of the police despite the formal attempts of the security reform to avoid this outcome. Both difficulties have intertwined to actively hinder the planned police reform, specifically the implementation of democratic policing strategies focused on crime prevention with a communitarian approach (i.e. Community-Oriented Policing). While the focus of this article is unpacking the connections of gender and security in El Salvador, Community-Oriented Policing (COP) serves as an empirical example to discuss 'How the gendered expectations of security in El Salvador hindered the security reform and the ongoing implementation of a democratic police?'.

This article argues that the security policy is gendered and rests on expectations that privilege a masculine and militaristic approach. As a result, the police favor short-term, operative police tactics as a response to violence and criminalization in the country. This occurs despite the police's simultaneous public advertisement of its use of integral social approaches to security and a new community-oriented approach to policing. This eloquent contradiction speaks of the gendered expectations of the security approach in El Salvador-which naturalize a masculine nature-, and the limits and disparities evident in the definition of the subject of security. As it stands, the subject of security is state- centric, thus, the focus of security is still engaged in the logics of the defense of the territory-a means to legitimize the use of force by the state.

This article responds to its central question by analyzing the empirical findings of a six-month data collection process in El Salvador-split into two periods in 2018 and 2019-in contrast with secondary data detailing Salvadoran security policies. The research was mainly carried out in San Salvador and its metropolitan area, with some visits to rural areas in Santa Ana and Cabañas departments. The data referred to includes three semi-structured interviews with senior police officers; four group-interviews with female and male police agents; and three semi-structure interviews with feminist women organizations. Unless personal names were already part of public information, all the names used in this research have been changed to protect the identities of the participants.

The argument proceeds as follows, in the first section I briefly discuss why is relevant to discuss gender and security from a feminist approach, situating the case of EI Salvador and drawing on a feminist-inspired discussion of the gendered and violent nature of Salvadorian security policy. In the second section, I argue that the state has adopted a masculine identity that directly affects the security policy in terms that privilege a male experience of security-allowing for the militarization of security. To illustrate this position, I briefly introduce the history of the Salvadoran police and the clash of interests that exists between traditional policing and COP. The third section illustrates how privileging masculine expectations to the police has implications for the involvement of women in the work of the police. It also addresses the discussion of how gender approaches can support a process of transformation of militarized policing into democratic police, with the inclusion of women's and LGBTI people's security concerns for the implementation of Community-Oriented Policing.

\section{A Short Note on the Limits to Existing Gender and Security Research in El Salvador}

Situating this article within the context of academic and policy-driven discussions regarding the post-conflict (in)security in El Salvador, it has become evident that there is a considerable literature on the topic of policing in the country. However, it is also evident that there is a significant gap in this literature with regards to the issue of gender and human security. Most of the existing literature on the Salvadorian police addresses the political, social and security issues of the post-agreement period. The majority of literature also focuses on the Peace Accords and the immediate institutional adoption of democracy after the war. Mainly employing a traditional state-centric analysis, the discussion has focused on the implementation of the Accords, the lessons learned [5-7]; and the difficulties that accompanied the security sector reform with a focus on the creation of the new police [8-10].

Studies emerging in the 1990s attempted to explain the 
recurrent high levels of criminality and the challenges to the post-conflict governments [11,12]. Additionally, scholarly work done in the late 1990s and early 2000s focused on post conflict security and channeled the discussion towards the questionable construction of the youth gangs as the problem of security. Influential studies discussed the gangs and their impact on security [13-18]. Other researchers focused on the responses by different governments and the politicization of security that followed the construction of a security narrative in El Salvador [19-22]. Some studies also focused on the role of the elites and the economic and political processes in the construction of a weak democracy and a failed state of security for the majority of the people [23-25]. However, none of these studies directly referred to the police and policing.

A second wave of research was more closely aligned with feminist concerns given its focus on the role of women in the post-conflict period, and specifically in the peace building process. It was concerned with the change of roles from being combatants or supporters of the revolution, to political actors and peace and development activists [2628]. The late post-conflict period in the early 2000 s also saw the resurfacing of scholarship focused on women and security. This scholarship studied and discussed gender-based violence in the form of feminicides and criminalization of abortion in a patriarchal and machista society[29-32].

While there is a great deal of literature dealing with security and gender in El Salvador, very little research has paid attention to the intersection between gender and security. Even less research has specifically discussed the structural operation of the police and the gendered nature of security policy. This article addresses some of the gaps in the literature by discussing the gendered nature of the security policy in El Salvador from a feminist perspective, specifically by observing how the gendered nature of the security policy influences the implementation of new approaches to policing. The article aim is to contribute to a new and growing literature focusing on different approaches to policing that can reduce violence through prevention and community relations, such as Community-Oriented Policing [33].

\section{Why a Feminist discussion on Gender and Security?}

It is important to acknowledge how the Security Reform negotiated in the Peace Agreement in 1992 echoed the security discussion that was taking place in international contexts during 1990s, in an emergent post-cold war environment. The discussion raised a critique of the narrow military orientation of the realist security paradigm, suggesting a shift in security to include ordinary people's concerns. Proposals were made to 'focus on the individual as the subject of security' [34]; and to question the primacy of the state as the referent of security. Challenging the 'national security' approach, 'Human Security' emerged as a new paradigm. At its core, human security is concentrated on the individual and a wider spectrum of security threats that could happen within and outside the state. These threats include concerns regarding development and human rights, as a replacement to the traditional focus on state-centered security based on military and territorial defense [34].

Furthermore, Feminist Critical Security scholars have been challenging the traditional equation of security with the military defense of the state $[35,36]$ by inquiring about the individuals and the contexts for whom and where security is defined. In doing so, they connect militarized state security to women's insecurities to expose the masculinity embedded in traditional security thinking [35]. Feminist theories, therefore, render explicit "how gender is deeply implicated in the way in which particular bodies experience and execute threat and violence"[35]. In this sense, feminism invites a radical re-thinking of security to bring the category closer to individuals and the way everyday life is impacted by and has an impact on security thinking [36]. Critical feminist approaches to security are then closer to a more human approach to security, in comparison to traditional realist approaches to security. A human security approach, considering its critiques, takes seriously the notion that people can be insecure within a secure state because the nature of their threats are different than those of the state; meaning that the state has the potential of becoming a threat to people [34].

The subject within the human security approach has commonly been the person, which is integral to 'citizen.' However, the person is never neutral, and its meaning is embedded in the socio-cultural construction of sex, gender, class, race and political affiliation [37]. Hence, a feminist perspective also helps to challenge the definition of the subject of security. Furthermore, a critical understanding of security challenges the alleged objectivity or subjectivity of security to connect it to a socio-cultural construction that creates a social order [38]. Therefore, if a security approach does not address these issues, it overlooks its gendered and socially biased construction and omits its impact on people's everyday experiences. Human security in the context of this article is understood in dialogue with feminist studies as an approach that rests on the person instead of the state, but recognizes the plurality of identities that conform the subject; remaining vigilant of the various possibilities where diverse ways of living can be threatened by the state [34].

In El Salvador, feminists also challenge a traditional notion of security, by recognizing the different security needs of women, men, and of the LGBTQ population in the country within the diversity of their social mobilizations. They question how these needs intersect with other social characteristics such as class, race, age, disabilities, and occupation to understand different positions of power. Instead of further developing this intersectional understanding of the differentiated security needs, however, I argue in this article that security in El Salvador is militarized because it only defends the interests of the state. Therefore, by adopting and adapting a feminist approach, I can establish 
a theoretical foundation that helps to explore the impact of gender expectations and masculinity, in relations of power within the police and between the police and heterogeneous communities. Hence, this approach provides a way to understand violent community-police relationships and the increase in cases of gender-based violence (GBV) against women within the police.

\section{Gendered Security in El Salvador: between a Soft and a Hard Position}

After 12 years of intense armed conflict and the prioritization of counter-insurgency strategies as the state's security policy [39], in 1992 the Peace Accords and the Security Reform promised a fresh civilian beginning for a post-conflict nation. The security reform mandated the creation of the new National Civil Police (PNC), which were to receive mandatory training at a new National Academy of Public Security [40]

With the aim of creating a new civilian-police body, the Peace Accords established quotas for the number of excombatants, from both the dismantled public security forces and the demobilized guerilla forces members (ibid.). A ratio of $60 / 40$ was set giving favor to a civilian majority, and the equal distribution of the remaining ratio between excombatants. The new police body was trained under a novel civilian security doctrine focused on human rights and democratic values, and in opposition to a military instruction. For this reason, the National Academy of Public Security (or ANSP, by its Spanish acronym) was created as an autonomous and civilian academic body with the responsibility of training and professionalizing the police focusing on the service to the community. Besides professionalization, the quota system supported the idea of national reconciliation between former enemies. This idea, however, was threatening to turn the PNC into a new scenario of political dispute [41]. The politicization of the police can also be explained with the resistance of the military and the conservative political elites to its creation. This resistance, and subsequent acceptance of military personnel into the police, would retard the consolidation of its civilian and democratic mandate $[4,7]$.

Security reform in El Salvador pledged to not only be humanitarian in focus, but gender neutral in approach. Distancing itself from a gender sensitive perspective, the security concerns discussed in the reform only responded to the promise of human security, in the sense that they re-focused the object of security to the individual. However, that individual, as feminist security scholars had previously critiqued, has been understood as neutral only to leave the question about 'the subject matter and politics of security' out of the negotiations [42]. In other words, gender was not recognized as intrinsic to understanding the configuration of the subject of security, therefore, neither the meaning of security nor the recipient of that security and the context where security would take place, were questioned [35].

Consequently, there was neither a discussion on the different gender roles performed by men and women during the war, nor on the social norms and expectations, including the differential needs and difficulties that they would encounter in the post conflict. From a critical feminist approach, gender neutrality could be reframed as a 'gender blindness' created by a male perspective, which reinforces gender inequalities in society. Therefore, without contemplating the security concerns raised by feminist scholars and organizations alike, it is possible to say that it lacked gender awareness in the definition of security and the role of the state as guarantor and architect of security [43].

Furthermore, the discussion introduced by Critical Security Feminists that questioned gendered myths and assumptions associated with militarized security, connecting them to the marginalization of women from security and privileging men in a dominant position [44], was ignored. Hence, women were not included in the peace negotiations despite their having taken an active role in the civil war, organized around the need for peace, and pushed for dialogue $[27,28]$. Only three high-ranking female FMLN commanders took part in the negotiations, and although they raised gender concerns, their participation was not as women but as ex-combatants [28]. Hence, there is very little evidence of the impact they had inside the negotiations in terms of bringing gender awareness into the Peace Accords $[28,45]$. As it was reported by 'Las Dignas', a leading Salvadoran women's organization, "there is not any reference to women either in the words nor in the spirit of the accords" [46]. Therefore, in accordance to the critics from Security Feminist scholars, the reform did not challenge the dominant focus of security within the state whereby it has historically represented men's interest and women's subjugation [43].

For the newly created police, however, the Accords gave a special consideration to female recruitment, but no specific quotas were established to guarantee it [47]. The fact that there was no specific gender quota highlights not only the gender blindness in the process but also the lack of understanding of gender expectations in the Salvadorian society. The lack of gender awareness in the discussion failed to open an equal space for women in a public security institution, and no consideration was given to the specificneeds women had in order to access a space dominated by men. Thus, the fact that women participated did not change the gendered constitution of the institution or benefited other women in terms of the security policies, something reflected in the low numbers of women in the PNC. The first promotion only had 3 women in the highest level; 8 women in the executive level, and 11 women in the basic level, in comparison to 30,65 and 260 men, respectively [48].

It is widely understood that giving attention to gender is not limited to the recognition of women [44]. Giving attention to gender in the Salvadorian context is acknowledging that the failure to reflect on the different gender experiences during the war neglected the recognition of gendered power imbalances, and failed to interrogate about who is or should be the subject of security [49].The resulting 'gender blind- 
ness' in the Peace Agreements became another form to naturalize a male perspective [28], which justified a statecentric discourse and a traditional masculine-driven security approach $[35,36]$ to deal with the new post-conflict context. Bringing a Feminist critique to a Salvadorian gender awareness should then "delegitimize discriminatory practices and institutions as socio-historical constructions and 'repoliticize' orthodox views on security by challenging the role of the state as provider of security" [42].

Feminist critiques of discriminatory practices based on gender, such as the division of the public-private space, and the visibility of the state as a male-constructed institution, is a way to bring attention to the politics at play in the construction of security in El Salvador. The gendered nature of the security policy is a representation of the politicization of security in its masculine approach, which is performed through increased militarization, limiting its definition.

Because the definition of security is gendered, so are the institutions for security provision; this is to say that the practice of security is gendered. As it stands, security in El Salvador is not neutral and mostly focuses on public spaces. Thus, despite the introduction of gender and COP philosophy into the work of the police, the implementation of security by the police in El Salvador is dependent on political agendas that seem to prioritize a masculine perspective on security by privileging the use of militaries over the introduction of more civilian and communitarian approaches to security.

\section{War against Gangs}

Security has been at the center of public attention since the end of the war. Amplified by media outlets, the high homicide levels and the social unrest have come to justify the introduction of immediate responses to security. This includes highly repressive measures such as massive detentions or the intensification of military and police presence in the territory [50], in detriment of more integral approaches to reduce violence. Nevertheless, from a critical perspective, the increase in security measures during the last 25 years has not been successful in reducing the homicide level in the country or in addressing the security needs of all the population.

The popularity of repressive security strategies has its origin in the securitization of the social problems that affected the country after the war. The increased militarization is rooted in the influence the armed forces have in the definition of the security agenda, even after the security reform took place. The Salvadorian political elite purposely created the discursive conditions justifying war-like responses i.e. the creation of a new enemy, and the re-introduction of a war-like paradigm of security to combat the enemy. In this context, it proved to be easy to justify immediate responses, even those using violent means, to a society that was long used to violence and tired of insecurity [21]. The military was once more brought into the public security sphere.

The dichotomous military and civilian expectations within the PNC in El Salvador, are explained in terms of the military/ guerrilla and civilian quota structure and the bricolage style of the initial police training. According to high-ranking police officers interviewed in the Metropolitan area of San Salvador, the quota system that fractured the police into political alliances and allowed the military to retain their influence in the new police became a weakness of the PNC, and what could be named as its 'original sin,' [4]. In addition to the military influence within the police, the fact that the PNC was initially trained based on different police models hampered it from building its own police model and fully integrating the mandate of the Peace Accords in its practice. Therefore, the struggle between a military and a civilian approach in the police is also explained in terms of the training the PNC received in its forming stages under the ONUSAL mandate, as various countries with different policing models influenced the constitution of the new police. The two most influential training models came from Spain, the United States (Puerto Rico), and Chile, which from 1992-1994 oversaw the 'Police Intervention' training program. Each of them brought their own approaches to policing [51]. In an interview with a high-ranking police officer in San Salvador, he mentioned that the National Police Body of Spain focused their training towards a democratic and civilian practice, while the Carabineers of Chile and the Puerto Rican Police, which had a military police structure, focused more on discipline and order.

It does not come as a surprise that this diversity of approaches to policing enriched the new police's identity, as much as it negatively affected the implementation of a locally owned approach to the specific Salvadorian context. This became a limitation when the police landed in the middle of political interests that reflected these two different police training models, allowing for the increasing involvement of the military in public security. This has been a major difficulty for the PNC, as it will be explained below.

From a feminist perspective, to paraphrase Laura Sjøberg, militarism is the introduction of a war-related mindset and activities outside of war-contexts into social and political life [52]. The introduction of war-contexts is what justified the militarization of the security in El Salvador. According to Jeannette Aguilar [4], the role of the military in the internal security has three main periods.

The first period is 1992-2002 i.e. the years after the Peace Accords. During this time, the governing party took advantage of the social instability of the postwar to reformulate the security discourse in the country. Because of a lack of personnel in the new PNC, members of the military were introduced into the patrolling work of the police but under the guidelines of the PNC [4].

The second period is 2003-2006 and the implementation of Mano Dura (Iron Fist) and, subsequently, Super Mano Dura security policies. This period initiated the 'War on Gangs', and successfully reversed the focus of security from the citizens to the state, identifying youth gangs as an issue of supreme priority for the security of the country $[17,20,53,54]$. As Josefina Echavarría explains [49], 
the consequence of a state-centered security is that when the object of security is self-reflected and remains unquestioned, its capacity to map social insecurities is limited. Therefore, everything becomes a security concern [49]. In El Salvador, the recycling of war paradigms of security and the notion of a 'public enemy' were reintroduced as ways to justify military intervention in public security. Furthermore, according to Aguilar [4] the impact of these years of intense militarization of the police was a process of denaturalization and internal decomposition. The use of violence permeated the inner fibers of the police. Indeed, even after the Super Mano Dura plan was officially over, the abusive practices and excessive use of force and violence remained in the police subculture [4]. The police continued to target young poor and marginalized men, resulting in a backlash that led to the strengthening of the gangs and their mutation into more organized forms of delinquency [4].

From a feminist critical perspective, this securitization could be labelled as a 'masculinist-security paradox', because it aims to repress violent masculinities by legitimizing state-supported masculine display of violence through the militarization of public security. The success of securitization in El Salvador has resulted in the introduction of militarism as a justifiable approach to public matters of security that are civilian by definition, which blurs the distinctions between war and peace, military and civilian [52]. While suggesting that insecurity has its roots in the use of violence by other groups different to the state, securitization has created a war-like scenario that renders invisible the socio-economic problems of the population and the political intentions of those in power. This blurry distinction between military and civilian is problematic on many levels. For the purpose of the implementation of community-oriented policing, a war-like logic becomes especially problematic when defining the role of the community in the process, as the community could be labelled either as a possible 'enemy' or as a potential 'informant'. This approach does not break damaging stereotypes, nor does it allow the police to strive to understand the social positionality of each community. Moreover, it limits the understanding of COP and its potential for social transformation.

The change of government in 2009 brought a change of political discourse and initiated a new third period of development from 2009 until 2014 [4]. It encouraged the PNC to go through changes that challenged earlier militarist and macho practices. In this period, the COP model was formally adopted and a Gender Unit was established, yet these changes did not translate into a change to security practices. Aguilar terms this period as one of 'militarization by decree' [4].

During this period, the executive sanctioned seven decrees, and the legislative sanctioned one, extending the participation of the military in different roles concerning public security. Consequently, militarization became the de facto security policy implemented by the FMLN administration, irrespective of the proposed strategic and inclusive approach to decriminalization [55]. During this time the military increased their role in public security, removing the barriers put in place by the Peace Accords to limit the direction of policing to civilian authorities. For instance, Brigadier General Francisco Salinas was appointed as the Director of the Police in 2012, replacing Commissioner Carlos Ascencio who had a COP approach. This was done based on the argument that delinquency was at a level beyond the capacities of the civilian police [4]. Nevertheless, COP was officially implemented by the time Brigadier General Salinas was appointed, thus his position as the PNC's general director did not stop the introduction of COP but did hinder its implementation.

It can be said that as security reform directly places powerful interests into question, it is as much a political process as it is a police-technical one [41]. It is for this reason that it took the PNC almost 20 years to formally embrace its communitarian mandate, and to recognize the different experiences of women and men within the police, as well as to implement gender policies for the institution.

\section{The Introduction of COP in the PNC}

In his opening speech in 2009, Commissioner Carlos Ascencio-the appointed police director at the beginning of the FMLN presidential period-, called for a re-evaluation of the police's development. He argued that strengthening the police as an institution required an institutional self-critique of the initial conception of the police in close relation to the community, and proposed the introduction of an integral approach to security that prioritized preventive measures and community-oriented practices [56]. Community-Oriented Policing (COP) is understood as a transversal policing philosophy that prioritizes the community in the processes of identification and solution of problems, as well as in the evaluation of the police work [57]. Since then, COP has been mainstreamed into the PNC first as a philosophy of policing, and more recently as a strategy and a policing model.

The first attempt to implement community policing was through the Community Police Intervention Patrols (PIPCOM, by its Spanish acronym), which were created during the Francisco Flores administration (1999-2004) and within the framework of the Alliance for Security. These patrols received funding and technical guidance from the US Department of Justice's Criminal Investigative Training Assistance Program (ICITAP).

Commissioner Hugo Ramirez, former sub-director of Public Security (until 2019), was the first to implement a PIP-COM in Zacamil, Mejicanos. According to him, the model aimed at effective patrolling to offer responses to crimes affecting communities such as drug dealing and robberies. The PIP-COM sought to reduce crime through planned preventative-dissuasive patrolling, quick response times, community integration and consultation. This approach was novel in that the patrolling was done by foot, bicycles, or by car in groups of four agents, with the intention that the police agents had more chances to be involved with 
the community. The plan was to gradually implement this program and expand it to the rest of the country. However, due to insufficient funding as well as limited follow up and monitoring, it was unable to establish itself firmly enough to take root in the work methodology that had inspired it.

In a 2018 interview with Hilda, a middle-ranking police woman, she explained that when she started working with the police, the PIP-Com's model was already established. Hilda commented that these ended up becoming more akin to intervention patrols than community policing: "they were more PIP than Com". This overemphasis on intervention patrolling policing, the PIP part of it according to Hilda, can be explained by the first period of justified militarization of the police [4]. Despite being classified as 'a failure,' because of a lack of institutional support and a clear communitarian strategy that turned the PIP-COMs into repressive groups [58], this format remains active in El Salvador, performing duties very similar to those described at its origins. Nevertheless, more serious steps toward a community-based model began in 2006, when the Department of Community Relations was made a Secretariat with greater authority to design and execute policies. Under that Secretariat, the Community Police Unit began the task of systemization with support from the ANSP, which concentrated on drafting the Experimental Manual on Community Policing.

The current COP model has been strongly supported on a technical level by the Japanese Development Agency, JICA, since 2011 until today. The terms of their support include the drafting of the Manual on Community Policing, the construction of COP bases, and the exchange with members of the Military Police of Sao Paulo, Brazil. The Police Pacification Units (UPP, in Portuguese), became a source of inspiration for the implementation of repressive tactics vis-à-vis the establishment of COP, especially in areas with high presence of gangs where the territory was disputed.

The UPP is a tropicalization-and one could say a militarization-of the Japanese Koban model, where communitarian-security bases are placed in local communities. In Rio and Sao Paulo, this model was implemented by the Military Police to 'clean' favelas of drug traffickers and gangs, enforcing law into these areas with military strategies, to be able to introduce a new communitarian police base in the intervened areas [59]. According to Commissioner Ramirez, the UPP's failed because of lack of sustainability of the model. First, because the police was the only institution in areas abandoned by the state, resulting in the UPP's model of first enforcing law, then setting up preventive programs with a communitarian approach, and leaving afterwards did not stabilize the areas or made a security project sustainable. Second, as their preventive programs with the community were not state-led but sporadically sponsored by private companies, they lacked economic sustainability. In this sense, according to Commissioner Ramirez, the Salvadorian model has exceeded the UPP and learned from its failures.

The Salvadorian police domesticated the tropicalization of the COP model done by the Brazilian Military Police, by implementing it as a strategy to dismantle the gang control over certain territories. Commissioner Ramirez expressed that COP in El Salvador has been projected differently, being more integral and long-term. Nevertheless, other voices from the police criticize the instrumental role assigned to COP and claim that there is still little understanding of community policing. Early in 2019, Pedro, a mid-ranking police officer in San Salvador, stated in an interview that COP in El Salvador is more ambitious in comparison to its implementation in Brazil, because the PNC works with a COP philosophy on a national level. There is, however, a need to evaluate whether the methodology and the strategy have been adequate. This is because,according to him, "a shortsighted culture has taught us to not look beyond but to react to situations, jamming us (in the PNC) to the delinquent problem and not allowing us to even do effective investigations. And this is also because a whole social phenomenon has been charged to the police".

Nevertheless, COP was introduced after two periods of militarization, meaning that the already fragile police force's civil practice has been under military influence for more than a decade, privileging a violent masculine expectation on the practice of policing. Moreover, the construction of gangs as a security concern that needed to be contended by means of heavy-handed measures, was already deeply implanted in the mentality of the people. Within the police, it worked to continue the war-notion of the 'enemy,' making it difficult to transform with a communitarian approach.

\section{COP: Rambo vs. Sissy Police}

Pedro, the mid-ranking officer in San Salvador, also argues that there is a cultural resistance to the COP model within the police, and a misconception of the mission of the police as an institution, and the role of the police as an agent. According to him, the Salvadorian Constitution defines the mission of the PNC is to prevent and repress crime. However, many in the police perceive that their mission is mainly to enforce the law and repress crime. Pedro claims that the average police agent perceives his role as being based on a "Rambo" prototype created by Hollywood movies, where the police agent is always either capturing or fighting crime, but not working on prevention. Prevention and particularly COP are associated with "soft" and "gentle" characteristics. In other words, they are seen as 'sissy policing'. This reference to supposed effeminate behavior genders the use of violence within the police and the perception police agents have of their role.

The Salvadorian police commonly state that people in El Salvador are violent. This is often followed with the statement "it is difficult for the police to respect all the human rights of all the people' because 'one cannot be blandito (soft)". Supporting Pedro's statement, being soft in their eyes is a synonym of being weak. Dominant masculinities are not weak, or at least the projection of masculinity is not weak. From a masculinity studies perspective Kimmel states, "manhood is about defense against humiliation" [60]. 
For that reason, for the police agents the use of force is not only necessary but encouraged among each other when they start working in the streets. Furthermore, Connell argues that violence is an important element in the political structure of gender between men [61]. Therefore, violence or force can be used to reclaim masculinity within group struggles. In a social decomposition process violence is used as a form of dominance that is imperfect because it is not legitimate. In the case of the police, the filtrated military logics fractured the fragile new civilian approach, and naturalized the need to prove the use of force and violence as a masculine faculty in a context of social and economic emasculation [62]. The same logic, however, thrives within gangs as violence is used as an expression of power and identity $[15,20]$.

With this expectation of masculinity, COP is rendered as soft policing. Therefore, many police officers are of the opinion that community policing is an additional conceptual approach to policing that can be omitted once graduated from the ANSP, because it is not the 'proper' way of policing the Salvadorian streets. As different police agents stated in informal discussions and group interviews, 'what you learn in the academy is theoretical and there is no use for it in the streets.' Hence, from their perspectives the implementation of COP is supplementary to existing repressive strategies. According to Pedro, the filtration of the military in security and the lack of implementation of COP relate to state institutional weakness, which the FMLN administration aimed to overcome by strengthening the public security body. For Pedro, this demonstrates that there is a limited understanding of security and its practice by the police. For this police officer, the methods implemented in the attempts to strengthen the State's capacity have been counter-productive to the COP model as they focus on repressive strategies that can provide speedy results by weakening delinquent structures and 're-gaining' control of the territory.

An example of military strengthening of the public security practice to overcome the state's institutional weakness, can be seen in the 'swept and COP' strategy, institutionalized since April 2018 by the administration of Sanchez Cerén as 'Plan 10.' This plan's focus is on the reduction of delinquency, and the control of the territory, with more presence of PNC in urban areas, and the conjoint work of PNC and Armed Forces in the rural areas [63]. In this plan, Community-Oriented Policing has been instrumental to promote the perception of policing practices that are done in consultation with the community while, nonetheless, the practice is based on military action, inspired in the Brazilian UPPs. Hence, in this plan COP strategies have been introduced in High Delinquent Incidence Sectors (SAID, in Spanish), as stabilizers of security after special security forces have 'swept' the area from gang members.

The paradoxical relationship between institutional weakness and a limited understanding of security, as previously pointed by Pedro, can be explained if security is understood as a public good that is provided by the state. Then, the weakness of the state contributes to the gradual erosion of this understanding of security [64]. Therefore, if the state is weak, there are fewer expectations on what it can do to transform the situation of violence; there is also less accountability, and a pressure for short-term results, which justify shock tactic approaches. For Pedro, this is a logic of 'cleaning the ground' that translates to the deployment of special security forces rather than community-oriented policing into violent contexts. From his point of view, this perspective limits the role of the police in the fulfillment of their mission, as the police is merely understood as a crime repressor instead of a service-oriented agent; reproducing the Rambo-like mentality that gives more value to operative shock strategies than to community-oriented strategies. There is a direct relation between the implementation of security practices and the definition of security by the state.

The 'Plan 10' security plan falls into this logic that Pedro critiques, as it is targeting mainly socio-economically disadvantaged communities with high levels of delinquency, with the intention to 'clean' the area of delinquency and gang structures. This strategy seems to be based on an unsustainability Rambo mentality, and is problematic for several reasons. The first and most obvious is the notion of 'cleaning' a community, in order to offer speedy security results, which replicates a war-like logic of the 'internal enemy' [37], based on the notion that communities can be cleaned from unwanted individuals. This is problematic not only because it constructs categories of 'lives that matter,' but because it also ignores the socio-economic context and the conditions that allowed for the consolidation of delinquency and gangs in the territory. Second, the idea of introducing COP to stabilize an area with the intention to evacuate after it is 'stable' is taking advantage of the communities. Since this security intervention does not address the social problematics affecting the communities, it is exploiting their needs to adapt and survive, and the trust mechanisms developed between community and police members. These social problematics should be addressed by other state institutions different from the police, for that reason it is questionable that the state pretends to 'stabilize' the conditions of these communities exclusively through the sporadic presence of the police.

Furthermore, this plan clearly differentiates the two policing styles in the country but also merges them together to make military approaches to public security appear sustainable. However, the sustainability of this plan depends on the sustainability of COP in the territories. Nevertheless, when the whole COP approach is not taken seriously by the PNC itself, and depends on the willingness of the local police members, this sustainability is hindered by the same plan's short-term design.

On a field visit to a rural community in the department of Cabañas, in March 2018, it was apparent how fragile COP can be when its role in a short-term security plan is merely instrumental. According to community representatives, the community used to be peaceful until it saw a spiral of violence in 2017 initiated by gang's territorial dispute, causing displacement of many families and young 
people to Mexico and the United States, as well as many homicides of members of the community. The police came with shock tactics in an open confrontation with gang members, and many were killed, and others were sentenced to prison. After this intervention, a new police group was sent to the community. This time it was the rural police's turnequipped with rifles and a community-oriented discourse-, to stabilize the situation and built trust relationships with the community. According to Giovanny, a police agent in charge of the sector, building trust-relationships with the community was very difficult at the beginning. They tried to follow the script and go door-to-door around the community, explaining their job and getting information from the people. It did not work as planned; people were afraid of them and distrusted them. Instead, these police agents saw an opportunity to interact with members of the community elsewhere. In this case, trust had to be built away from the 'typical' security discourse; in this case, the football field became the place where the police showed the community they could be trusted.

The rural police earned the trust of the children and youth that used the field by guarding their games and supporting their tournaments, eventually earning their parents trust and having a snowball effect within the rest of the community. This trust, according to the community representatives, was possible because the police stayed in the community and got to know the people that lived there, especially the youth. Now that the plan is over and the place is safer, the community fears the withdrawal of the rural-police and the 'sporadic' patrol done by new police who do not know the needs of the community. The community believes that once the rural police is removed, the youth will be targeted again, and crime will return amidst rampant social insecurity. In these contexts, a COP strategy can only be sustainable if it takes part of a long-term plan that includes the community, and not just of a short-term approach to mask military action under the effectivity of community-policing.

Nevertheless, securitization and militarization have been planted deeply into the security logics of the country, despite the change of administrations and political discourse. Consequently, despite the spread of COP, Martínez [54] has claimed that Sanchez Cerén "launched the most violent and murderous repressive strategy that EI Salvador has seen this century". Since 2016, the Sanchez Cerén administration launched the program Extraordinary Security Measures to crack down on the gangs, focusing on restrictions in the prison system, legal reforms to the criminal procedure code, among others, and again, militarization. By normalizing the military inherence in the internal security and their operative support to the police, this administration embraced a strategy of open war against the gangs, further justifying the use of lethal force [65].

Following this logic, communities with higher levels of criminal violence and torn social fabric, but not prioritized as the SAID, often do not have the presence of community policing units and only interact with militarized units.
These units mistreat them to the extent that women from a rural community in central El Salvador suggest that "there is more fear towards them (the police) than the boys (gangs)". For those communities who have a presence of police that actively approaches them, the police represent a threat and jeopardize their security within their communities as it flags them as collaborators with the police. Hilda, the mid-ranking police woman, also reflected on this situation in one of our interviews, discussing how problematic the heavy-handed measures were for the community-police relationship. "When the gangs began, instead of looking for real causes and looking for alternatives that really accounted for the phenomenon, more repressive and harder measures were adopted. (...) You could not see anyone on the street because we did take them all to jail. (...) Then, when we wanted to get closer to the community and see what we could do, many communities did not want the police to come. They were vulnerable". In these cases, people do not trust the police because in their everyday reality, encounters with the police are marked by fear and repression. Therefore, understand the community policing philosophy not as a concrete effort of the police, but as an instrumental discourse to get close to the community during the day, extract information, and repress them at night with special units.

As Cynthia Enloe expresses it, "militarization occurs because some people's fears are allowed to be heard, while other people's fear are trivialized and silenced" [66]. In masculine driven societies, such as El Salvador, men feel constant pressure to prove their manhood by means of aggression; thus, the introduction of a military mindset in the police has, for example, legitimated the use of violence as a successful proof of masculinity. Following the use of the military-police special forces, in comparison to 2015 , when El Salvador gained the infamous title of being the most violent country not at war in the world, with a homicide rate of 104 per 100,000 inhabitants, the homicide rate in 2016 was reduced to 81.2 per 100,000 inhabitants, to 60 in 2017, and 51 per 100,000 in 2018 [67]. Although these numbers are still considered to be epidemic by the World Health Organization, the administration of Sánchez Cerén proudly highlighted the decrease in homicides, calling for the successful implementation of the security strategies. In parallel, a strategic silence was kept about the increase in the abuse of force by the police and the numerous cases of extra-judicial killings of alleged gang members by Special Security commands within the PNC $[68,69]$, the increase in the killings of women [70], and members of the LGBT community [71]. So far, there seems to be a correlation between the reduction of homicides, the increase in extrajudicial killings, the increase in gender-based violence, and violent-militarized masculinities.

\section{The Gendered Nature of Security in Practice}

It is possible to assert that the State operates with a notion of security that is masculinist. This gives higher visibility 
to 'public' security concerns, while it remains silent around other forms of insecurity and violence caused by accepted definitions of masculinity. In an attempt to bring public awareness to other forms of violence affecting women, feminist and women's organizations point to the high levels of feminicidios (femicide) [72] The number of feminicides makes El Salvador one of the most dangerous countries in the world for women. Women's organizations hold the state for being partially responsible for the impunity shown towards the perpetrators of the 1,518 cases of feminicide reported from January 2015 to June 2017 [73]. Feminicide, or the killing of a women based on gender, became a crime in the Salvadoran jurisprudence with the introduction of the LEIV (Special Law for a Life Free from Violence for Women) in January 2012. Despite the creation of the new law, most of these killings have been categorised by the police as homicides. The designation of a killing as a feminicide is only made possible once the investigation has confirmed that women had been killed because of their gender, and rulings on this are dependent on the investigation of the crime and the interpretation from the judge.

The problem of impunity is made further visible in the high number of women killed in EI Salvador i.e. 13,49 for every 100,000 in 2017 according to data from the PNC [74]. Compared to 2017, with 471 feminicidios, 2018 saw a $20 \%$ reduction in the killings of women and, according to the PNC, there were 381 feminicides. According to the information gathered by the women's organization ORMUSA, many of these cases happened in the private sphere or in locations that are familiar to the victim [75].

According to women organizations, there are also cases were women have been kidnapped by organized crime. However, there is has been a very poor record kept by the police with regards to the registration of reports of these kind [76]. According to a representative from the women organization Las Dignas, "women do not have major protection from anyone," the police and the military, as well as the gangs, threaten them. However, this experience is not reflected in the public narrative, in which there is no discussion about women being perceived as sexual objects or suffering from sexual harassment, sexual violations, and feminicide. In further discussions with other members of Las Dignas, amongst women, there are socially invisible groups, such as lesbians, which suffer discrimination in society. This is reflected in their difficulties to access health services, and experiences of lack of respect and harassment from security forces. The Trans-community also reports high levels of impunity in connection with the hate crimes perpetrated against them since 1990. These are calculated by LGBT Human Rights Organizations to be as high as 600 [77]. These organizations, such as COMCAVIS, and ASPIDH-ARCOIRIS, state that gang members and the police threaten transgender people; while the gangs use them as carriers of illegal activities, the police criminalize them based on this stereotype [78]. There is also structural violence. Without state recognition as a gender specific group trans people find it difficult to access social services.
Challenging the public security narrative takes us to question the silence around gender in connection to the differentiated impact lethal violence has on different bodies. Therefore, men being killed by other men, in connection to criminality or the 'war against gangs', has been normalized in the public narrative, while women and other gender minorities' deaths, whom are mainly killed because of their gender identity or their gender expression, remains accepted but invisible. These gender-based crimes, taking the form of feminicides and transfeminicides, are supported by the patriarchal construction of ownership of female bodies and a need to reaffirm masculinity by attacking those that do not comply with a hetero-normative model [79]. This has a twofold effect. On the one hand, it hides the gendered dimensions of violence, downplaying non-normative expressions of violence-such as domestic forms of violence and violence against women and girls, or hate crimes-from the public sphere, thus locating them in the private sphere and not challenging the silence around them. In addition, by only focusing on violence against women as a gendered type of violence it perpetuates the notion that men are not gendered, masking the impacts of a masculinist approach to violence, mainly in its militarized form and the securitization of the public agenda.

\section{Gender Awareness in the Police}

Women and LGBTI organizations have lobbied for laws or protocols that recognize their specific security concerns and ways to protect them from violence. In 2010 the LEIV was sanctioned. This law acknowledges seven different forms of violence that affect women in the everyday life and that remain invisible to the public eye. These are economic violence, feminicide violence, physical violence, emotional and psychological violence, patrimonial violence, sexual violence, and symbolic violence [80]. LGBTI organizations, on their part, have lobbied for protocols against discrimination and for inclusion. The Executive Decree No. 56 to reduce discrimination against LGBTI population was sanctioned in 2010, and the Attention Policy for the LGBTI Population was sanctioned in 2018. Still, these bureaucratic measurements have had little ripple effect on the everyday police agent in terms of challenging masculine, misogynistic, and hetero-normative ideas. Reports suggest that the police are recognized as violators of the human rights of women and LGBT people, particularly trans women $[31,71]$.

Responding to a new political ideology and the pressure from feminist and LGBTI Organizations, in 2009 there was a presidential mandate to incorporate gender diversity and vulnerable groups into the work of the police. The creation of a Gender Unit and a Gender Equity and Equality Policy were implemented as part of the Institutional Strategic Plan of the police for 2011-2021. Furthermore, the article 25 of the LEIV stipulates the creation of institutional units for assisting women victims of violence. Following this mandate, the PNC established Special Womens' Units for Support and Attention, which specialized in gender-based violence 
against women. The units were organized under the Office for Reporting and Attention to Civilians (UNIMUJER-ODAC in Spanish). The intention of these units is to provide a separate, comfortable and safe space for women to denounce crime and abuse without being re-victimized. These units also represented the possibility of offering a differential approach to women's insecurities, including transgender women. However, this inclusion depends on the informed discretion of the personnel from each unit, as the LEIV does not directly include trans-women but other protocols sanction discriminatory actions by state institutions.

The creation of special units for women have proved to be an important opportunity to create a trust relationship between the police and the women from the communities, because (as women organizations warn) 'community is not a synonym of women' [81], and spaces with a differential approach are welcome in different communities. There are examples, one comes from the community of Texistepeque, where one female police agent has developed 'a good COP practice', according to the PNC, by evaluating the conditions of the community and offering alternatives to mitigate social risks. In this case, agent Ana Maria saw that the lack of income-generating activities in a shrinking agricultural economy was a risk for both for males and females of the community, that needed to be addressed. Therefore, in dialogue with the community and with the support of the PNC, she organized training courses to offer women and men in the community professional skills they could use to be economically independent. Through these courses and her interest in the social conditions of the community, the agent began to be more involved in the everyday concerns of the community, and the community began to organize themselves more. In the everyday involvement trust relationships were consolidated, allowing the police to map other insecurities that were elusive before, such as economic and social insecurities related to the lack of jobs in the area. As well as cases of sexual or domestic violence, drug dealing, and gang related threats to members of the community. This example addresses differential security concerns of the community that go beyond the traditional police approach but gets closer to a broader definition of security that prioritizes the community.

The police, however, still have difficulty understanding the complex position of women in the communities. Women, including trans-women, are vulnerable to violence in areas controlled by gangs for different reasons. Some of those are related to being family members, friends, or neighbors of gang members [31]. In discussions with young women living in gang-controlled areas, they expressed a constant fear of being kidnapped, raped or killed by the gang members. As the coordinator of ORMUSA's Violence against Women's program highlights, "women live in a mortal duality", as whatever they do, in terms of denouncing, informing, or resisting/ tolerating violence, is perceived as double betrayal to the gang and to the police. Therefore, many of these women are in a difficult position that reflects the power tensions in the community between the police and the gangs. In these cases, the social control operated by the gang impact the legal power attributed to the police and its faculty for public security. Therefore, in some cases the UNIMUJER-ODAC's capacity to register cases and map the specific insecurities of women in some communities has weakened because of the security risks affecting women and their families if they contact the police. Besides these risks, fieldwork shows there is a general mistrust in the judicial system, characterized by impunity, especially when a victim is a woman or member of the LGBT community and comes from a low socio-economic class $[79,82,83]$.

If gender relations between women and diversity groups with the police are detrimental for the former, it is striking to see the insecurities' female police officers face within the institution itself, and how these reflect power relations in society. Given that the police are immersed in the country's cultural gender constructions, policewomen encounter many difficulties in attempting to fulfill their work. According to Hilda, a middle-ranking police woman, there is a problem with gender within the police because many men in power still think there is no need to make changes that can differentially include women, or to make women visible. Men still think that the space for women is at home.

"The problem with gender is that men believe that when it comes to women there is no need to make changes. Because they still believe that, the things that are said for them are also said for us. And when we want to make use of those laws that are written in male, simply when they make legal interpretations, they say no, that (those laws) refer to men. So? And they do not want to make us visible in the laws either. It is very complicated, even despite all the individual will that exist, of some men who are in important positions, the assumption that it is not necessary for women to be visible prevails. And I think many are still thinking that our space is cooking and taking care of children" [84].

Hilda's statement reflects the difficulties for women to access law in general. In the police, she says, there is a similar situation. By the time of the interview in 2017, there were 2,875 female officers in total in the institution in comparison to 20,095 policemen. Of those, only 21 women are in high-ranking roles compared to 138 men, and 79 women are in mid-ranking roles in comparison to 735 men. These numbers are telling of the remaining gender gaps within the institution.

It is very common for policewomen to experience verbal abuse from policemen, regardless of their rank. There are around 1-2 accusations daily. Furthermore, according to female police participants in the group interview, there are many reasons for this, some of which are related to gender stereotypes that position women as weak and in need of protection, which hampers women's police in operative work. Another common problem women police encounter is sexual harassment by other police members, which reflects power imbalances at work, a macho culture, and poor infrastructure for women to feel safe.

Therefore, by becoming aware of the mechanisms within the police to ensure gender equity and equality, a diverse 
group of female officers is acknowledging the remaining unequal power structures and the different forms of violence they experience in their work. Led by the Gender Unit of the PNC and supported by feminist organizations, they have organized themselves in a network as supporters and protectors of their rights i.e. the Women Defenders Network of Human Rights of Women working in the National Civil Police. The intention of this network is to support women in the police to denounce cases of abuse, violence, or discrimination in their work environment. The network also works to support the leadership position of female police within the institution. Furthermore, this network of female police, as well as the women special units, can be understood as an attempt to close the gap between policy and practice in the implementation of gender and COP. In their current situation, they remain imperfect examples of gender-sensitive approaches to human security policies, because even though they include a differentiated security need, from the perspective of women, they are still relegated from an institutional discussion about the meaning of security and the role of gender. The Gender Unit in the PNC with the support of women organizations has attempted to open these discussions within the police, but they remain marginalized in a rigid hierarchical structure.

Loyalty to the institution is stronger than strategic gender alliances. Thinking back on the gender imbalance in police members, it is striking to see how male dominated the police in El Salvador remains regardless of attempts to make it more inclusive. This characteristic is similar to the almost exclusively male constitution of the military. Even though women have taken military roles since 1980, they "have not challenged the state military's essentially masculinized culture" [44]. The PNC remains a brotherhood, not a sisterhood. This was shockingly demonstrated by the feminicide of the police agent Carla Ayala, shot and disappeared by another police agent in an official car on December $28^{t h}, 2017$. After the news went public, it took the PNC nine months to find her remains and more than a year to determine it was a case of feminicide. The agent who killed her is still a fugitive $[85,86]$.

Cases of feminicide within the police are not new but remain invisible because of the macho culture that dominates. Rendering these cases visible and creating gender selfawareness is a difficult task when women in the institution feel they must prove themselves as worthy of the job and loyal enough to be accepted into 'the pack'. Therefore, the case of Carla Ayala shook the police at the deepest level and challenged the naturalization of gender-based violence against women within the institution. This demonstrated that beyond gender mainstreaming, there is a need to transform the cultural constructions and understandings about gender and the use of violence, as this not only affects the development of the police as an inclusive institution but also its approach to their policing work. For the successful implementation of COP and gender, there is a need to revise the PNC's own system of accountability within the institution and towards the community [87].

\section{Conclusions}

The 1992 Peace Accords and Security Reform were an opportunity to de-militarize, professionalize and create a new security paradigm in El Salvador based on a civilian focus and mandate that could safeguard a sustainable peace. However, research focused on current realities reveals that the objectives of this reform are closer to unfulfilled promises than to actual transformations within the police and the overall security structure.

This article reveals that the security reform focused on the structural transformation of the military and the police failed to sufficiently question the meaning of security or the identity of the subject of security and the security provider. By neglecting to question the object and matter of security in a country that had been under military rule almost since its foundation [4], the relationship between male dominance, the state, and security was ignored. Masculine security logics were portrayed as being gender neutral. However better reframed as gender blind, the security logic in El Salvador has rendered invisible the differential experiences of insecurity and violence in the country by restricting security to criminality, while naturalizing forms of gender-based violence against women and sexually diverse groups and ignoring the socio-economic origins of post-war insecurity. The gendered construction of security and the limits of its definition have restrictively gendered the work of the police, privileging repressive tactics to address crime and insecurity instead of new approaches to policing that could reduce violence and bring social transformation, such as Community-Oriented Policing.

I have argued above that the gendered nature of security policy allowed post-war administrations to justify the introduction of military personnel and logics into internal security policy and policing in the country. Furthermore, the presence of ex-combatants in the new police, made possible through the quota system, contaminated the early development of this institution and revealed it to be a new political battlefield. All the administrations that followed the 1992 Peace Agreements have until present constructed and strengthened a narrative of security based on a warlike scenario that reminds of the 12 years of confrontations between the guerrillas and the state.

I have also highlighted above that prevalence of a masculinist state and the privileging of male dominance and the cultural associations of violence and masculinity, has not permitted the implementation of integral approaches to security and models of policing that prioritize community work over operative strategies with the objective of reducing violence. In this context, fieldwork reveals that the local police agents found themselves between the need to fulfill their duties as preventers and repressors of crime, implementing COP while taking part or acknowledging joint military-police operations in similar communities, if not the same, in the name of security. These military-police operations have validated the performance of violent masculinities within the PNC to the level that police students newly graduated 
from the ANSP already know that they will have to assume a tough approach to policing in the streets if they want to be accepted. Women police officers also feel a constant need to prove they can perform a tough, almost violent masculinity in order to be accepted into operative work.

This paper argues that, by failing to question the subject of security and its gendered dimension, it has been impossible to secure good results from the introduction of COP in El Salvador. I suggest that this is because the police do not operate in a cultural or social vacuum but is embedded in society. Socio-cultural assumptions that value and justify dominant and authoritative expressions of masculinity over the autonomy of the female body and the recognition of other forms of violence, influence the state responses to insecurity and, therefore, the focus of the police towards repression instead of prevention. Privileging militarized security strategies renders other forms of policing as less efficient, effective, and, thus, less masculine. In this context, COP has become little more than a marginal approach to policing and gender no more than a mainstreamed formality.

Nevertheless, when the subject of security is stretched and the different security needs of women, men and LGBTI population in the community are included, it creates alternatives able to transform community-police relationships by means of challenging militarized expectations and 'violent' traditions within the police. The discussion presented in this article illustrates the idea that when the subject of security is challenged and gender is not ignored, policing can take other forms and focus more on the people it aims to serve, making room for the implementation of democratic policing to take place in the form of community-oriented practice. Therefore, more efforts and research need to be put into understanding and supporting the transforming gendered expectations of security within the police, as a bottom-up approach to gender mainstreaming the security policy in El Salvador.

\section{Acknowledgements}

This research is a part of the Community-Based Policing and Post-Conflict Police Reform Project (ICT4COP). This project has received funding from the European Union's Horizon 2020 research and innovation programme under grant agreement No 653909. I would like to thank the police agents and communities in El Salvador who shared their knowledge and experiences with me. I would also like to thank the researchers and law enforcement professionals whose valuable comments helped shape this paper, and especially: Ingrid Nyborg, Cecilia Agger, and John-Andrew McNeish. I would also like to extend my gratitude to the two anonymous reviewers who provided constructive critical comments during the peer-review process.

\section{References and Notes}

[1] Cornejo I, Alas S. Un Año Sin Carla Ayala. Available from: https://elmundo.sv/un-ano-sin-carla-ayala/.

[2] Beltran J. Asesinato de Carla Ayala Fue Punto de Quiebre para Sepultar al GRP. Available from: https://youtu.be/D6D6KxTk4JM.

[3] Cruz JM, Aguilar J, Vorobyeva Y. Legitimidad y Confianza Pública de la Policía en EI Salvador. Resumen Ejecutivo. San Salvador, El Salvador: Instituto Universitario de Opinión Pública, Universidad Centroamericana José Simeón Cañas; 2017. Available from: http://www. uca.edu.sv/iudop/wp-content/uploads/Legitimidad-y-confianza.pdf.

[4] Aguilar J. 4. In: BöllEditor FH, editor. El Rol del Ejército en la Seguridad Interna en El Salvador: Lo Excepcional Convertido en Permanente. Asociación Equipo Maíz; 2016. pp. 61-83. Available from: https://mx.boell.org/sites/default/files/reconceptualizacion_de_ la_violencia_web-final.pdf.

[5] de Soto A, del Castillo G. Obstacles to Peacebuilding. Foreign Policy. 1994;(94):69-83. Available from: https://www.jstor.org/stable/ 1149132. doi:10.2307/1149132.

[6] Spence J, Vickers G, Dye D. The Salvadoran Peace Accords and Democratization. A Three Year Progress Report and Recommendations. Hemisphere Initiatives; 1995. Available from: http: //lanic.utexas.edu/project/hemisphereinitiatives/three_year.pdf.

[7] Vilas CM. Un Balance de la ejecución de los acuerdos de paz en El Salvador (An assessment of the implementation of thepeace agreements in El Salvador). Papers. 1996;49. Available from: https://core.ac.uk/download/pdf/39002070. pdf. doi:10.5565/rev/papers/v49n0.1827.

[8] Kincaid AD. Demilitarization and Security in El Salvador and Guatemala: Convergences of Success and Crisis. Journal of Interamerican Studies and World Affairs. 2008;42(4):39-58. doi:10.1111/j.1548-2456.2000.tb00159.x.

[9] Stanley W. Building new police forces in El Salvador and Guatemala: Learning and counter-learning. International Peacekeeping. 1999;6(4):113-134. doi:10.1080/13533319908413801.
[10] Wolff D. Police Reform in El Salvador: The Corner Stone of a Renewed Security Agenda. Seguridad Ciudadana. 2015;pp. 1-24. Available from: http://www.fespad.org.sv/police-reform-in-el-salvador-thecornerstone-of-a-renewed-security-agenda/.

[11] Bourgois P. The Power of Violence in War and Peace: PostCold War Lessons from El Salvador. Ethnography. 2001;2(1):5-34. doi:10.1177/14661380122230803.

[12] Pearce J. From Civil War to "Civil Society": Has the End of the Cold War Brought Peace to Central America? International Affairs. 1998;74(3):587-615. doi:10.1111/1468-2346.00036.

[13] Cruz JM. Central American Maras: From Youth Street Gangs to Transnational Protection Rackets. Global Crime. 2010;11(4):379_ 398. doi:10.1080/17440572.2010.519518.

[14] Decesare D. The Children of War Street Gangs in El Salvador. NACLA Report on the Americas. 1998;32(1):21-29. doi:10.1080/10714839.1999.11725660.

[15] Hume M. '(Young) Men With Big Guns': Reflexive Encounters with Violence and Youth in El Salvador. Bulletin of Latin American Research. 2007;26(4):480-496. doi:10.1111/j.1470-9856.2007.00239.x.

[16] Rodgers D. Joining the Gang and Becoming a Broder: The Violence of Ethnography in Contemporary Nicaragua. 2007;26(4):444-461. doi:10.1111/j.1470-9856.2007.00234.x.

[17] Rodgers D. Slum Wars of the $21^{\text {st }}$ Century: Gangs, Mano Dura and the New Urban Geography of Conflict in Central America. Development and Change. 2009;40:949-976. doi:10.1111/j.14677660.2009.01590.x.

[18] Rodgers D, Muggah R. Gangs as Non-State Armed Groups: The Central American Case. Contemporary Security Policy. 2009;30(2):301317. doi:10.1080/13523260903059948.

[19] Van Der Borgh C, Savenije W. De-securitising and Re-securitising Gang Policies: The Funes Government and Gangs in El Salvador. Journal of Latin American Studies. 2015;47(1):149-176. doi:10.1017/S0022216X14000741.

[20] Hume M. Mano Dura: El Salvador Responds to Gangs. Development in Practice. 2007;17(6):739-751. doi:10.1080/09614520701628121. 
[21] Wolf S. Pacification or Escalation in El Salvador's Gang Territories? NACLA Report on the Americas. 2017;49(3):290-297. doi:10.1080/10714839.2017.1373947.

[22] Wolf S. Mano Dura: The Politics of Gang Control in El Salvador. University of Texas Press; 2017. Available from: http: //www.jstor.org/stable/10.7560/311219.

[23] Montoya A. The Violence of Democracy Political Life in Postwar El Salvador. Palgrave Macmillan; 2018. doi:10.1007/978-3-319-763309.

[24] Wade CJ. Captured Peace: Elites and Peacebuilding in El Salvador. Ohio University Press; 2016. doi:10.1017/S0022216X1700102X.

[25] Wolf S. Subverting Democracy: Elite Rule and the Limits to Political Participation in Post-war El Salvador. Journal of Latin American Studies. 2009;41(3):429-465. doi:10.1017/S0022216X09990149.

[26] Ibáñez AC. 8. In: Moser CON, Clark FCE, editors. El Salvador: War and Untold Stories-Women Guerrillas. Zed Books; 2001. pp. 117-130. Available from: https://www.jstor.org/stable/4029805.

[27] Roggeveen E. Revolutionary Women in El Salvador: The Farabundo Martí National Liberation Front, Women's Organizations, and the Transformation of the Position of Women [PhD Thesis]. Bryn Mawr College. Bryn Mawr, PA, USA; 2003. Available from: http: //hdl.handle.net/10066/393.

[28] Saint-germain MA. Mujeres '94: Democratic Transition and the Women's Movement in El Salvador. Journal of Women Politics \& Policy. 1997;18(1997):75-99. doi:10.1300/J014v18n02.

[29] Hume M. The Politics of Violence: Gender, Conflict and Community in El Salvador. Bulletin ed. Wiley-Blackwell; 2009.

[30] Prieto-Carrón M, Thomson M, Macdonald M. No More Killings! Women Respond to Femicides in Central America. Gender \& Development. 2007;15(1):25-40. doi:10.1080/13552070601178849.

[31] Vaquerano V. Violencia Contra las Mujeres en El Salvador. 1. Friedrich Ebert Stiftung; 2016. Available from: https://library.fes. de/pdf-files/bueros/fesamcentral/12926.pdf.

[32] Zulver J. High-risk Feminism in El Salvador: Women's Mobilisation in Violent Times. Gender \& Development. 2016;24(2):171-185. doi:10.1080/13552074.2016.1200883.

[33] Zoethout MA. Recuperar el Control Estatal en Territorio de la Mara Salvatrucha: Un Análisis a partir del Acuerdo "Santa Tecla Municipio Libre de Violencia". Policía y Seguridad Pública. 2015;5(7):179-246. doi:10.5377/rpsp.v5i1.1989.

[34] In: Human Security. Routledge;.

[35] Stern M. Naming In/security - Constructing Identity: "Mayan-Women" in Guatemala on the Eve of "Peace". Göteborg, Sweden: Department of Peace and Development Research, Göteborg University; 2001.

[36] Wibben ATR. Feminist Security Studies. A Narrative Approach. Routledge; 2011.

[37] Hudson H. In: Karamé KH, Tryggestad TL, editors. Gender as a Tool for the Analysis of the Human Security Discourse in Africa. NUPI, PRIO; 2000. pp. 79-113.

[38] Huysmans J. Security! What Do You Mean?: From Concept to Thick Signifier. European Journal of International Relations. 1998;4(2):226255. doi:10.1177/1354066198004002004.

[39] Molinari L. De "Sostén" a "Decidido Apoyo": Población y Contrainsurgencia en las Revistas Militares. El Salvador (1961-1972). Nuevo mundo / Mundos nuevos. 2017;doi:10.4000/nuevomundo.71345.

[40] Martínez-Peñate O. El Salvador: Los Acuerdos de Paz y El Informe de la Comisión de la Verdad. Nuevo Enfoque; 2007.

[41] Costa G. La Policía Nacional Civil de El Salvador (1990-1997). UCA Editores; 1999.

[42] Hudson H. 'Doing' Security As Though Humans Matter: A Feminist Perspective on Gender and the Politics of Human Security. Security Dialogue. 2005;36(2):155-174. doi:10.1177/0967010605054642.

[43] Shepherd LJ. In: Shepherd LJ, editor. Sex or Gender? Bodies in World Politics and Why Gender Matters. Routledge; 2010. pp. 3-16.

[44] Zalewski M. 'Well, What is the Feminist Perspective on Bosnia?'. International Affairs. 1995;71(2):339-356. doi:10.2307/2623438.

[45] Conaway CP, Martínez S. Adding Value: Women's Contributions to Reintegration and Reconstruction in El Salvador. Gammage, s ed. Naraghi Anderlini S, editor; 2004.

[46] Las mujeres ante, con, contra, desde, sin, tras el poder político. San Salvador, El Salvador: Oxfam y Novib; 1995. Available from: http://www.lasdignas.org.sv/wp-content/uploads/2014/09/LAS-
MUJERES-ANTE-CON-CONTRA-DESDE-SIN-TRAS-ELPODER-POLÍTICO-1995_opt2.pdf.

[47] López RO, Quinteros C, Ramos CG. Reforma del Estado Después de los Acuerdos de Paz. Negociando e Implementando un Acuerdo Político Inclusivo en El Salvador. Inclusive Political Settlements. 2015;(13):24. Available from: www.berghof-foundation.org.

[48] Política Institucional de Equidad e Igualdad de Género de la Policía Nacional Civil 2011-2021. San Salvador, El Salvador: Policía Nacional Civil; 2011.

[49] Echavarría J. 2. In: Theorising Security Discourses. Manchester University Press; 2010. pp. 44-84.

[50] Reyna V, Hernández M, Esquivel E, Ramírez J. Inseguridad y Violencia en El Salvador. El Impacto en los Derechos de Adolescentes y Jóvenes del Municipio de Mejican. Publisher; 2017.

[51] Arévalo Herrera LC. La Formación Policial en El Salvador: Desafíos y Oportunidades para Impulsar un Modelo de Policía Comunitaria. Revista Policía y Seguridad Pública. 2014;1:143-164. doi:10.5377/rpsp.v1i1.1390.

[52] Sjoberg L, Via SE. Gender, War, and Militarism. Feminist Perspectives. PRAEGER Security International; 2010.

[53] Farber J. War in Peace: Exploring the Roots of El Salvador's Gang Violence. Council on Hemipheric Affairs. 2015;Available from: http://www.coha.org/wp-content/uploads/2016/07/War-inPeace-for-website.pdf.

[54] Martínez O. How Not to Assemble a Country. NACLA Report on the Americas. 2017;49(2):139-144. doi:10.1080/10714839.2017.1331801.

[55] Cruz JM, Aguilar J, Vorobyeva Y. Legitimidad y Confianza Pública de la Policía en El Salvador. Resumen ejecutivo. Instituto Universitario de Opinión Pública; 2017. Available from: http://www.uca.edu.sv/ iudop/wp-content/uploads/Legitimidad-y-confianza.pdf.

[56] Salvador PE. Cmsdo. Carlos Ascencio Girón - Director General. PNC [Online video]. Available from: https://youtu.be/D6D6KxTk4JM.

[57] Baltazar Laderos E, Padilla Oñate S, Villalobos García L. Los Aportes de la Academia de Seguridad Pública al Proceso de Reforma Policial en El Salvador. Policía y Seguridad Pública. 2016;2(6):81-114. doi:10.5377/rpsp.v6i2.2990.

[58] Reyna V. Estudio sobre las Políticas de Abordaje al Fenómeno de las Pandillas en El Salvador (1994-2016). 7. Friedrich Ebert Stiftung; 2017. Available from: https://library.fes.de/pdf-files/bueros/ fesamcentral/13897.pdf.

[59] Amar P. The Security Archipelago: Human-Security States, Sexuality Politics, and the End of Neoliberalism. Duke University Press; 2013.

[60] Kimmel M. The Gendered Society. Oxford University Press; 2004.

[61] Connell RW. 3. In: The Social Organization of Masculinity. Blackwell Publishers Ltda.; 1995. pp. 67-86. doi:10.4324/9780203958568.

[62] Theidon K. Reconstructing Masculinities: The Disarmament, Demobilization, and Reintegration of Former Combatants in Colombia. Human Rights Quarterly. 2009:31(1):1-34. doi:10.1353/hrq.0.0053.

[63] Plan 10: Medidas Priorizadas y Apuestas Institucionales Complementarias Período de Abril 2018 a Enero 2019. San Salvador, El Salvador: Secretaria Técnica y de Planificación de la Presidencia;.

[64] Abello Colak A, Pearce J. De una Policía Centrada en el Estado a una Centrada en la Comunidad. Lecciones del Intercambio entre las Policías Comunitarias de Bradford en el Reino Unido y de Medellín en Colombia. Bradford, UK: University of Bradford, International Centre for Participation Studies; 2009. ICPS Documento de Investigacion Nr. 9. Available from: http://hdl.handle.net/10454/3845.

[65] Zablah NR. Sánchez Cerén: "Aunque Algunos Digan que Estamos en una Guerra, No Queda Otro Camino". El Faro. 2016;Available from: https://elfaro.net/es/201603/el_salvador/18180/S\%C3\% A1nchez-Cer\%C3\%A9n-Aunque-algunos-digan-que-estamos-enuna-guerra-no-queda-otro-camino.htm.

[66] Enloe C. The Morning After: Sexual Politics at the End of the Cold War. University of California Press; 1993.

[67] Clavel T. InSight Crime's 2017 Homicide Round-Up. InsightCrime. 2017; Available from: https://www.insightcrime.org/news/analysis/ 2017-homicide-round-up/.

[68] Barnes L. US-backed Special Forces Accused of Human Rights abuses in El Salvador. ThinkProgress. 2018;Available from: https://thinkprogress.org/us-backs-el-salvador-police-accusedof-human-rights-abuses-5f4a44a44050/. 
[69] Callamard A. Declaración Final de Misión en El Salvador. Geneva, Switzerland: Office of the United Nations High Commissioner for Human Rights; 2018. Available from: https://www.ohchr.org/SP/NewsEvents/Pages/DisplayNews. aspx?News ID=22634\&LangID=S.

[70] Calderon B. Gobierno Avala Establecer Alerta Nacional por Feminicidios. La Prensa Gráfica. 2018;Available from: https://www.laprensagrafica.com/elsalvador/Gobierno-avalaestablecer-alerta-nacional-por-feminicidios-20180503-0071.html.

[71] Van Dalen RA, Anderson CE, Bones SE, Dooley C, Grazioso I, llorio $\mathrm{M}$, et al. Uniformed Injustice. State Violence Against LGBT People in El Salvador. Washington, DC, USA: Georgetown Law Human Rights Institute; 2017. Available from: https://www.law.georgetown.edu/human-rights-institute/wp-content/ uploads/sites/7/2017/07/2017-HRI-Report-Uniformed-Injustice.pdf.

[72] Lagarde M. 7. In: Bullen M, Diez Mintegui M, editors. Antropología, Feminismo y Política: Violencia Feminicida y Derechos Humanos de Las Mujeres. Ankulegi; 2008. pp. 209-240. Feminicidio is a concept coined by Marcela Lagarde, a Mexican Anthropologist, derived from Diane Russell's femicide concept. While Femicide refers to the gender-based killing of women, Lagarde feared that the Spanish translation of the concept would only refer to women's homicide removing all the socio- cultural and political connotations of the concept. Therefore, Feminicidio, feminicide as I use it in this article, refers to the set of violations against the human rights of women, including crimes and disappearances of women, and adduces the responsibility to the State in terms of its inaction and the high levels of impunity. Feminicidio is a concept coined by Marcela Lagarde, a Mexican Anthropologist, derived from Diane Russell's femicide concept. While Femicide refers to the gender-based killing of women, Lagarde feared that the Spanish translation of the concept would only refer to women's homicide removing all the socio- cultural and political connotations of the concept. Therefore, Feminicidio, feminicide as I use it in this article, refers to the set of violations against the human rights of women, including crimes and disappearances of women, and adduces the responsibility to the State in terms of its inaction and the high levels of impunity.

[73] Informe sobre Hechos de Voiolencia contra las Mujeres. El Salvador 2016 y 2017. San Salvador, El Salvador: Ministerio de Justicia and y Seguridad Pública (MJSP) and Dirección General Estadística y Censos(DIGESTYC); 2018. Available from: http://aplicaciones.digestyc. gob.sv/observatorio.genero/docs/INFORME_LEIV_2016_2017.pdf.

[74] ONU Insta a El Salvador a Erradicar el Feminicidio. El Mundo. 2018;Available from: http://elmundo.sv/onu-insta-a-el-salvador-aerradicar-el-feminicidio/.

[75] Feminicidio-Observatorio de la Violencia de Género contra las Mujeres. San Salvador, El Salvador: Organización de Mujeres Salvadoreñas por la Paz;. Available from: http://observatoriodeviolencia. ormusa.org.

[76] Violencia Social-Observatorio de la Violencia de Género contra las Mujeres. San Salvador, El Salvador: Organización de Mujeres Salvadoreñas por la Paz;. Available from: http://observatoriodeviolencia. ormusa.org/violenciasocial.php.

[77] Violaciones de Derechos Humanos de las Personas Transgénero en El Salvador. Lista de Cuestiones sometida a las Naciones Unidas Oficina del Alto Comisionado para los Derechos $\mathrm{Hu}$ manos. COMCAVIS, ASPIDH ARCOIRIS TRANS, Generación HT, Heartland Alliance and Washington Collegue of Law; 2015. Available from: https://tbinternet.ohchr.org/Treaties/CCPR/Shared\% 20Documents/SLV/INT_CCPR_ICS_SLV_19856_S.pdf.

[78] CIDH. Una Mirada a la Violencia contra Personas LGBTI. Un Registro que Documenta Actos de Violencia entre el 1 de Enero de 2013 y el 31 de Marzo de 2014. Comisiòn Interamericana de los Derechos Humanos. Organización de los Estados Americanos; 2014. Available from: http://www.oas.org/es/cidh/informes/ pdfs/violenciapersonaslgbti.pdf.

[79] Asociación Entre Amigos IRLGR IHRC. The violation of the rights of lesbian, gay, bisexual and transgender persons in El Salvador. Shadow Report submitted to the United Nations Human Rights Committee; 2010. Available from: https://www.outrightinternational.org/ sites/default/files/439-1.pdf.

[80] Ley Especial Integral para una Vida Libre de Violencia para las Mujeres (Integral Special Law for a Life Free from Violence for Women). San Salvador, El Salvador: Asamblea Legislativa; 2011. Available from: https://www.transparencia.gob.sv/institutions/instituto-salvadorenopara-el-desarrollo-de-la-mujer/documents/5991/download.

[81] PNC, ORMUSA. Unidad Institucional de Atención Especializada a las Mujeres en Situación de violencia de la Oficina de Denuncia y Atención Ciudadana. Available from: http://belemdopara.org/unidad-institucional-de-atencionespecializada-a-las-mujeres-en-situacion-de-violencia-de-laoficina-de-denuncia-y-atencion-ciudadana-unimujer-odac/.

[82] IHRLC. Sexual Diversity in El Salvador. A Report on the Human Right Situation of the LGBT Community. International Human Rights Law Clinic; 2012. Available from: https://www.law.berkeley.edu/files/ IHRLC/LGBT_Report_English_Final_120705.pdf.

[83] Montti Velasco RM, Bolaños Vásquez HJ, Cerén Lovo AM. Situación de Violencia Letal Contra las Mujeres en El Salvador, Guatemala y Honduras. 2014 - Julio 2018; 2018.

[84] Hilda P. Personal Interview.

[85] Acan-Efe. Acusan a Policías por feminicidio de Carla Ayala. Available from: https://www.laprensagrafica.com/elsalvador/Acusan-a-policiaspor-feminicidio-de-Carla-Ayala-20190202-0209.html.

[86] Flores R, Hernández F. Carla Ayala: Un año de Impunidad que Retrata a El Salvador. Available from: https://www.laprensagrafica.com/elsalvador/Carla-Ayala-Un-anode-impunidad-que-retrata-a-El-Salvador-20181228-0314.html.

[87] Neild R. Temas y Debates en la Reforma de la Seguridad Pública. Una guía para la sociedad civil. Policía Comunitaria; 2000. Available from: https://www.wola.org/sites/default/files/downloadable/Citizen\% 20Security/past/comunity\%20policing\%20formatted--sp.pdf. doi:0929513-43-6 1630. 